\title{
The importance of remnant native vegetation of Amazonian submontane forest for the conservation of lizards
}

\author{
Silva, DJ. ${ }^{a *}$, Santos-Filho, M. ${ }^{a}$ and Canale, GR. ${ }^{b}$ \\ ${ }^{\text {a }}$ Centro de Estudos, Pesquisas e Desenvolvimento Agro-Ambiental - CPEDA - Universidade do Estado de \\ Mato Grosso - UNEMAT, Campus Tangará da Serra, MT 358, Km7, Jardim Aeroporto, \\ CEP 78300-000, Tangará da Serra, MT, Brazil

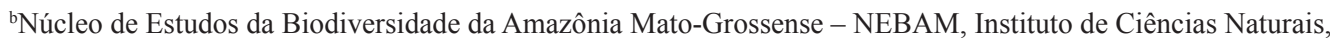 \\ Humanas e Sociais - ICNHS, Universidade Federal de Mato Grosso - UFMT, campus Sinop, Avenida Alexandre \\ Ferronato, 1200, Setor Industrial, CEP 78550-728, Sinop, MT, Brazil \\ *e-mail: dioneijs@gmail.com
}

Received: May 3, 2012 - Accepted: April 15, 2013 - Distributed: August 31, 2014

(With 2 figures)

\begin{abstract}
Forest fragmentation affects animal population dynamics mainly by loss of habitat and disruption of animal movement. Lizard assemblages are affected by environmental changes, but, depending on their ecological needs, some species might be more vulnerable than others. The southern Amazon suffers accelerated anthropic actions replacing natural environments by farmland (crops and pasture). This region is considerably drier than most of the northern Amazon, with stational semi-deciduous forests fragmented and isolated by pasture, and crops to a lesser extent. Here we report data on lizard assemblages using semi-deciduous forests, forest edge and the surrounding pasture in the southern Amazon in Mato Grosso, Brazil. Lizards were collected in 21 forest fragments (41 to 7,035 ha) surrounded by pasture; using pitfall traps placed on a degradation gradient - from pasture inwards forest fragment (up to $200 \mathrm{~m}$ ). We collected 242 individuals (14 species, seven families) in 6,300 trap-days. The pattern of species occurrence was largely nested and this nesting was associated with three habitat guilds (generalist, edge-tolerant, and forest species). Although there was no obvious fragmentation effect on lizards diversity community-wise, Hoplocercus spinosus, Bachia dorbignyi, Micrablepharus maximiliani and Kentropyx calcarta were more vulnerable to such effects than all other ten species collected. We verified that assemblages inhabiting pasture and forest edge are a nested subset of assemblages from the forest core. The remnant native vegetation is not distributed homogeneously and lizards species can persist in different parts of the landscape, therefore we recommend the protection of forest remnants as an important conservation action for lizards of the southern Amazon.
\end{abstract}

Keywords: herpetology, Amazon, community ecology, conservation, nestedness.

\section{Efeito de borda sobre a comunidade de lagartos em fragmentos de floresta semidecidual submontana ao sul da Amazônia}

\section{Resumo}

A fragmentação de florestas afeta a dinâmica das populações animais por meio, principalmente, da perda de habitat e interrupção dos movimentos dos animais. Assembléias de lagartos são afetados por mudanças ambientais, mas, a depender de suas demandas ecológicas, algumas espécies são mais vulneráveis do que outras. A Amazônia Meridional sofre ações antrópicas aceleradas substituindo ambientes naturais por terras voltadas para agropecuária (cultivos e pasto). Esta região é consideravelmente mais seca do que a maior parte das terras ao norte da Amazônia, com florestas estacionais semi-deciduais fragmentadas e isoladas por pasto, e, em menor extensão, cultivos agrícolas. Neste estudo apresentamos informações sobre uso de bordas e pastagem de lagartos confinados a fragmentos de florestas semi-decíduas no sul da Amazônia em Mato Grosso, Brasil. Foram coletados lagartos em 21 fragmentos florestais (41 a 7,035 ha) cercados por pasto; usando armadilhas de queda (pitfalltraps) colocadas em um gradiente de degradação - do pasto em direção ao interior do fragmento florestal (até $200 \mathrm{~m}$ ). Nós coletamos 242 indivíduos (14 espécies, sete famílias) com 6,300 armadilhas-dia. Identificamos 3 guildas de habitat (generalistas, tolerante a borda, e especialistas de floresta). Apesar da ausência do efeito da fragmentação sobre a diversidade de lagartos na comunidade como um todo; Hoplocercus spinosus, Bachia dorbignyi, Micrablepharus maximiliani e Kentropyx calcarata são mais vulneráveis a estes efeitos do que as outras dez espécies coletadas. Ademais, apenas quatro espécies habitam a matriz de pastagem, que foi aqui considerada um habitat inóspito para a maior parte da assembléia de lagartos. Finalmente, nós verificamos que as assembléias habitando pastagem e borda da floresta são subsets aninhados das assembléias presentes no interior da floresta. Recomendamos a proteção dos remanescentes florestais como uma ação de conservação importante para lagartos da Amazônia Meridional.

Palavras-chave: herpetologia, Amazônia, ecologia de comunidades, conservação, aninhado. 


\section{Introduction}

Deforestation directly impacts animal populations by the replacement of forestland by non-habitat land covers; in addition, forest fragmentation increases contact zones of forested environments with human-altered lands. Forest edges have a distinct microclimatic condition in relation to forest core, due to temperature increase, higher sunlight incidence, stronger wind stream and lower humidity. These factors affect vegetation structure and, consequently, animal population dynamics changing their ecological interactions (Bierregaard Junior et al., 1992; Laurance et al., 2002; Ricketts, 2001, Santos-Filho et al., 2008).

Forest fragmentation leads to the increase of forest edge in relation to forest core and it might have harsh consequences for most animals and plants (Fagan et al., 1999; Laurance and Yensen, 1991), changing their distribution, behaviour, and survival, due to habitat loss (Barbosa and Marquet, 2002; Murcia, 1995; Sartorius et al., 1999; Ishino et al., 2012). Such consequences may be evident up to $500 \mathrm{~m}$ inside a forest fragment (Laurance, 1991; 2000), but most of these effects are more obvious in the first $35 \mathrm{~m}$ (Rodrigues, 1998) to 60m (Lovejoy et al., 1986).

The matrix around a forest patch is a fundamental habitat for several species; but detrimental to several others, constraining their movements inside a single patch and making dispersal to a different patch difficult or even impossible (Fahrig and Merriam, 1994; Fischer et al., 2005; Gascon et al., 1999). Lizard movements in distinct matrices are significantly reduced in relation to movements in forested areas (Hokit et al., 1999).

Some species react positively to fragmentation effects, and their abundance increases close to forest edge, such as termites, grasshoppers and ants (Fowler et al., 1993), butterflies (Brown and Hutchings, 1997), and habitat generalist bird species (Bierregaard Junior and Lovejoy, 1989; Stouffer and Bierregaard Junior, 1995). On the other hand, there are a number of species that are sensitive to forest fragmentation and react negatively to its detrimental effects, such as flies, bees, wasps (Fowler et al., 1993), beetles (Didham, 1997), forest specialist ants (Carvalho and Vasconcelos, 1999), forest mammals and understorey specialist birds (Primack and Rodrigues, 2001).

Colli et al. (2003) and Silvano et al. (2003) report that fragmentation effects on lizards may vary among biome and also among species with different ecological needs. Cerrado species may be less affected than tropical forest species by fragmentation effects. In tropical forests of Costa Rica, Norops polylepis (Peters, 1874) changes behaviour and spends more time at the forest edge in the dry season, while in the wet season it spends more time in the forest core (Schlaepfer and Gavin, 2001). In the Atlantic forest, however, researchers did not find strong edge effects on herpetofauna (Colli et al., 2003).

In naturally fragmented forest, such as the Brazilian Cerrado, edges of forest patches may be occupied by species from open land, such as cerrado (sensu stricto). However, in areas of forest that are fragmented by human activities, there may be no species that are specifically adapted to open areas and edges may be colonised by subsets of the species that occurred in the original forest continuum.

The dry submontane forest (semi-deciduous forest) of southwestern Amazonia have been fragmented by extensive cattle raising activities and, despite proximity to areas of natural Cerrado on the southern border of the Amazon, the region may lack species specifically adapted to open areas. In this study, we investigate the assemblages of lizards using forest interior, edges, and pasture to determine whether the edge species are open-area specialists or a nested subset of the original forest fauna.

\section{Methods}

\subsection{Study area}

We sampled lizard communities of 21 forest fragments at the basins of Jauru and Cabaçal rivers, tributaries of the Paraguay River, in southwestern Mato Grosso in Brazil (15'15'6" S, 58 42'56" W and 15'33'43' S, 58 00'17' W) (see Figure 1). Three of our 21 study sites were located
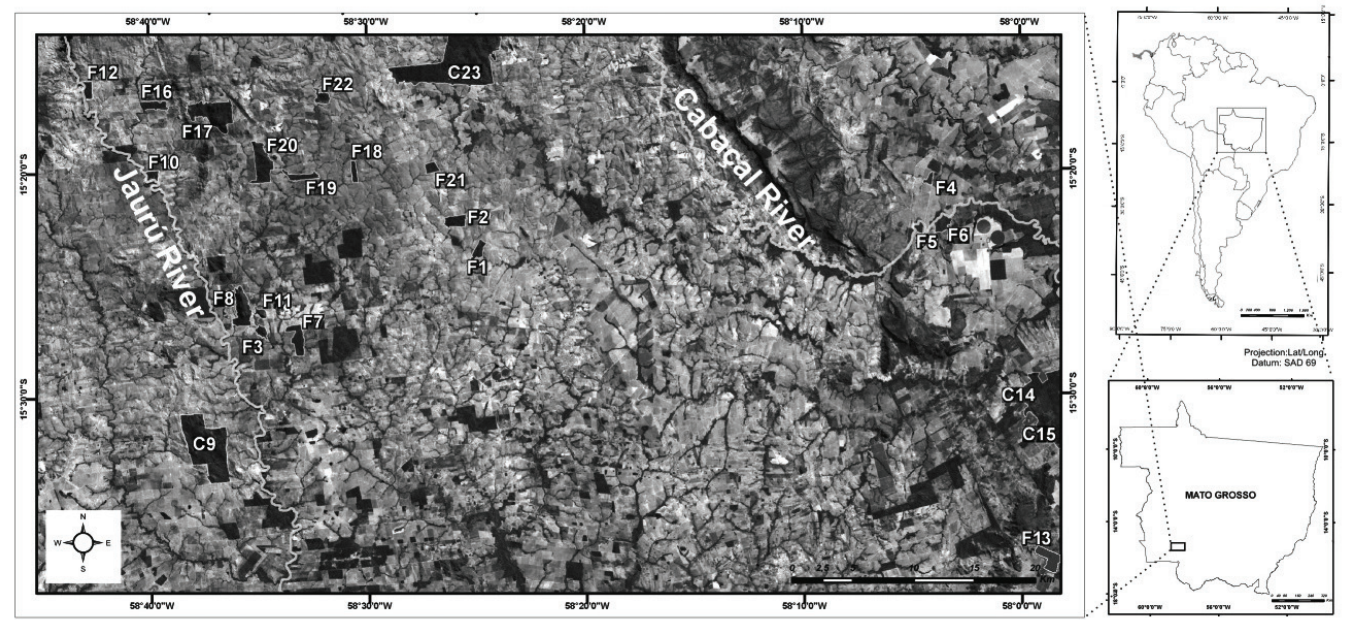

Figure 1. Map of study area showing forest fragments. 
in large fragments (larger than 1,000 ha) and 18 were in forest fragments ranging from 41 to 468 ha. The study was conducted between January and February (rainy season), and between July and August (dry season) for the years 2003 and 2004. Three areas were sampled simultaneously for 10 -d each. All sampled fragments had some anthropogenic alteration and were surrounded by pasture with similar grazing pressures.

\subsection{Vegetation and climate}

The vegetation of the study area is similar to that of the Amazon forest, but is not considered part of the dominant Amazonian climate (Brasil, 1985). It is a seasonal submontane semi-deciduous forest (Amaral and Fonzar, 1982), with elevation from 100-500 m.a.s.1. and eutrophic redyellow podzolic soils (Oliveira et al., 1982). The climate is seasonal tropical with evident rainy and dry seasons, and mean annual precipitation is $1330 \mathrm{~mm}$. Temperature reaches $38^{\circ} \mathrm{C}$, with a mean maximum temperature of $24.9^{\circ} \mathrm{C}$, and mean minimum temperature of $20^{\circ} \mathrm{C}$ (Resende et al., 1994).

\subsection{Pitfall trap sampling}

Pitfall traps are efficient to sample terrestrial/fossorial lizards (Cechin and Martins, 2000; Greenberg et al., 1994). We installed six lines of pitfall traps in each site. The first pitfall line was located on the pasture matrix, $50 \mathrm{~m}$ from the edge of the forest fragment, the second was placed in the forest edge, and the other four every $50 \mathrm{~m}$ within the forest, with the last pitfall line at $200 \mathrm{~m}$ from the edge. Each pitfall line was 50-m long, with five 24-litre plastic buckets placed every $10 \mathrm{~m}$. Buckets had the shape of a truncated cone, $37 \mathrm{~cm}$-height, 30-cm-diameter at the open-top, and a 26 -cm-diameter bottom (23.6 litres). They were buried to their rims in the ground and linked at ground level by an 80 -cm-height plastic guide fence, stapled to wooden stakes. The guide fence was buried $5 \mathrm{~cm}$ into the soil. During the rainy season, pieces of styrofoam were placed in the buckets, to avoid animals drowning, and buckets were periodically emptied of water. Pitfall traps were verified daily and remained open for 10 consecutive days.

\subsection{Visual search}

Visual search is a good supplementary method, because generally we are only able to sample terrestrial/fossorial lizards using pitfall traps (Campbell and Christman, 1982; Cechin and Martins, 2000). One person walked slowly (about $5 \mathrm{~m} / \mathrm{min}$ ) along 100-m transects located between two trapping transects (lines of pitfall traps). We carefully looked for lizards on trunks up to $1.5 \mathrm{~m}$-high and everywhere in the litter, up to $5 \mathrm{~m}$ from the transect. The procedure was conducted during the third and seventh sampling day from $900 \mathrm{am}$ to $1200 \mathrm{pm}$. Location, species and age were recorded. Animals were collected and deposited in the Instituto Nacional de Pesquisas da Amazônia/INPA and the Universidade do Estado de Mato Grosso/UNEMAT.

\subsection{Data analysis}

To evaluate the differences in richness and abundance of lizards among the degradation gradient (six trapping transects) we performed Wilcoxon test (Wilkinson, 1998) using Systat 8.0. In addition, to verify the nestedness of lizard assemblages we performed nest-analysis to calculate matrix Temperature (T) (Atmar and Patterson, 1993) using Aninhado (Guimarães Junior and Guimarães, 2006). Rarefaction curves were performed using EstimateS 7 (Colwell, 2005). We complied with Brazilian laws and obtained a license from the Environmental Brazilian Agency (IBAMA) to collect and transport lizards. License numbers 033/02; 004/03 and 057/04.

\section{Results}

In total we captured 242 individuals belonging to 14 species (seven families) in 6,300 trap-days. We identified three habitat guilds: four generalist species, which use forest and pasture matrix; six edge-tolerant species, using forest and edge but not found in pasture matrix; and four forest species, which are exclusively found inside forest patches at least $50 \mathrm{~m}$ from the edge (see Table 1).

Table 1. Total number of individuals captured in each transect in 21 forest patches.

\begin{tabular}{|c|c|c|c|c|c|c|c|}
\hline \multirow{2}{*}{ Species } & \multicolumn{6}{|c|}{ Disturbance gradient } & \multirow{2}{*}{ Habitat Guild } \\
\hline & Pasture & Edge & 50 & 100 & 150 & 200 & \\
\hline Tupinambis merianae & 2 & 3 & 1 & 1 & 0 & 0 & Generalist \\
\hline Ameiva ameiva & 7 & 5 & 1 & 2 & 2 & 5 & \\
\hline Stenocercus caducus & 3 & 14 & 4 & 10 & 5 & 10 & \\
\hline Cercosaura eigenmanni & 1 & 2 & 2 & 10 & 3 & 7 & \\
\hline Copeoglossum nigropunctatum & 0 & 5 & 5 & 5 & 5 & 17 & Edge-tolerant \\
\hline Gonatods hasemani & 0 & 5 & 12 & 10 & 12 & 13 & \\
\hline Iphisa elegans & 0 & 3 & 7 & 6 & 5 & 3 & \\
\hline Gonatodes humeralis & 0 & 4 & 0 & 2 & 1 & 2 & \\
\hline Norops fuscoauratus & 0 & 1 & 0 & 3 & 1 & 4 & \\
\hline Colobosaura modesta & 0 & 0 & 1 & 1 & 0 & 0 & \\
\hline Hoplocercus spinosus & 0 & 0 & 1 & 0 & 2 & 0 & Specialist \\
\hline Bachia dorbignyi & 0 & 0 & 0 & 0 & 2 & 2 & \\
\hline Micrablepharus maximiliani & 0 & 0 & 0 & 0 & 1 & 0 & \\
\hline Kentropyx calcarata & 0 & 0 & 0 & 0 & 0 & 1 & \\
\hline
\end{tabular}


There were no species found exclusively in the pasture. Tupinambis merianae (Duméril and Bibron, 1839), Ameiva ameiva, Stenocercus caducus (Cope, 1862) and Cercosaura eigenmanni (Griffin, 1917) were captured in pasture matrix, but only the first was not trapped in all gradient transects. Most of the species were found at the forest edge and inside forest patches, but only Bachiadorbignyi (Duméril and Bibron, 1839), Micrablepharus maximiliani (Reinhardt and Luetken, 1862) and Kentropyx calcarata (Spix, 1825) were exclusively found in forest core (more than $100 \mathrm{~m}$ from the forest edge) (see Table 1).

There was a lower diversity (abundance and richness) of lizards in the pasture matrix compared to the forest patches, considering all gradients ( 0 to $200 \mathrm{~m}$, from edge to core) (see Table 1) (abundance: Z-range $=3.26-1.98$, $P<0.05$; richness: $Z$-range $=3.21-2.24 ; P<0.05$ ). There was also higher lizard richness at $200 \mathrm{~m}$ compared to $50 \mathrm{~m}$ from the edge $(\mathrm{Z}=2.45, P=0.01)$. There was no difference in lizard abundance among all trapping transects covering the gradient from the edge to the forest core $(P>0.05)$.

Regardless of physical characteristics of the area, summing number of species collected in all forest fragments separated by each of the degradation gradients and pasture, there were an increase of number of species towards fragment core and the increment of species belonging to all distinct habitat guilds (see Table 1).

According to rarefaction curves for three categories of fragment size: a) 41 to $100.3 \mathrm{ha}$; b) 100.4 to $300 \mathrm{ha}$; and c) over 300 ha; we observed an increment in number of species towards the core of the forest fragments for all categories (see Figure 2).

Matrix temperature $(\mathrm{T})$ was 39.6 , confirming a nested pattern also observed in Table 1, indicating that diversity increases from the edge to the forest core.

\section{Discussion}

In the southwestern Amazonia, fragmentation of the original landscape dates back from the late 1950s, when large roads cut forested land and brought the first human settlements to the region; shortly afterwards, forest cover was converted to small agricultural crops and pasture for cattle raising (Cardille and Foley, 2003). The relevance of these human-driven alterations to the landscape is exacerbated by the large number of endemic plant and animal species at the ecotonal region, where this study was conducted (Fearnside, 1999).

Pasture was considered a low-quality microhabitat for most of the lizards found in semi-deciduous submontane forest in the Southwestern Amazonia. About 71\% (10 species) of lizards captured in this study were only found inside forest fragments (including forest edge); thus, forest fragmentation and habitat loss might act as a selective barrier for the dispersal of lizards among forest patches surrounded by pasture matrix, which may lead to stochastic losses of populations.

We did not observe a clear pattern in richness and abundance of lizards along the disturbance gradient
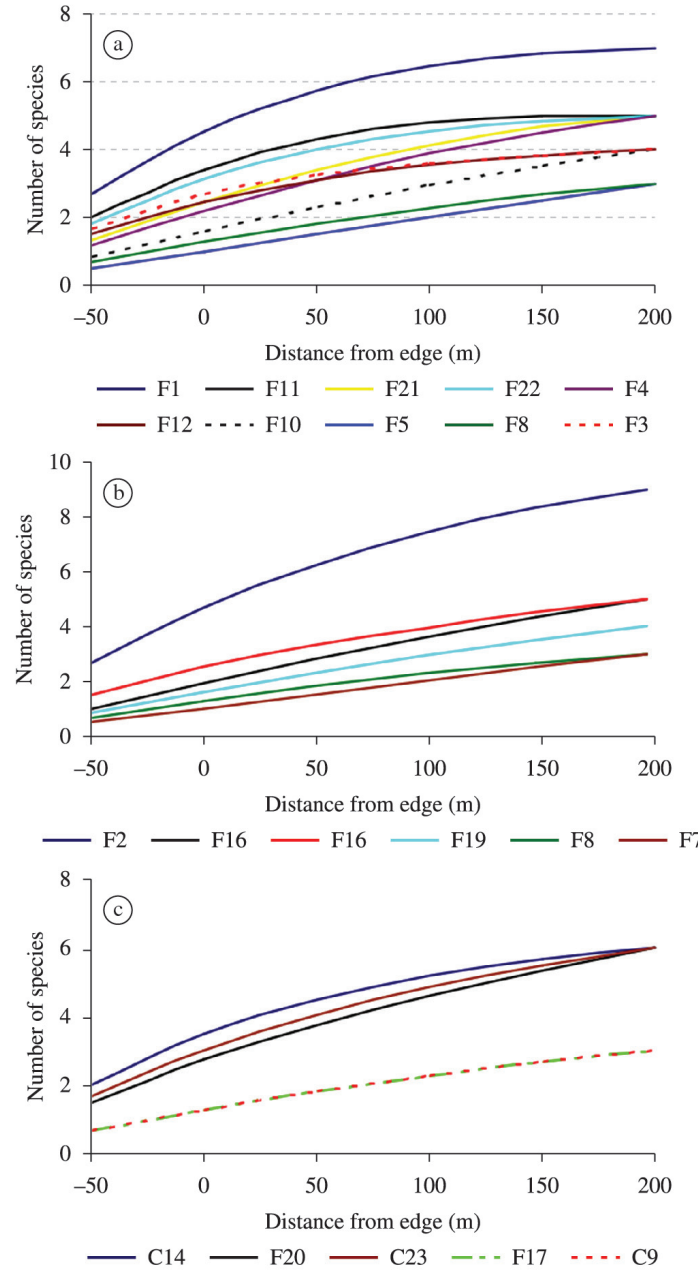

Figure 2. Rarefaction curves for number of species by edge distance. a) 41 to $100.3 \mathrm{ha}$; b) 100.4 to $300 \mathrm{ha}$; c) over 300 ha. $\mathrm{F}=$ small forest fragments; $\mathrm{C}=$ control areas (forest fragments larger than 1,000 ha).

(from edge to core), in accordance to a previous report for fragmentation effects on communities of lizards in Cerrado (Colli, 2003). However, we observed a nested pattern for the species composition of lizards along the same gradient, where those species present at the pasture matrix and at forest edge are subsets of the assemblage in the forest core. Not even one species was exclusively present at the pasture matrix and/or at the forest edge. A. ameiva was the most abundant species in pasture (54\% of all lizards captured), which corroborates other research and its classification as heliothermic that benefits from anthropic alterations (Colli, 1991; Vitt and Colli, 1994; Lima et al., 2001).

We identified T. merianae, A. ameiva, S. caducus and C. eigenmanni as generalist species, less vulnerable to forest fragmentation (Bierregaard Junior and Stouffer, 1997). S. caducus was observed in all sampled environments and was the most abundant generalist species ( $53 \%$ of captured 
species); accordingly, it is known to explore cerrado sensu stricto (savannah-like environment), gallery forests and may be present in human-altered environments (Strüssmann, 2000). The capability of these four species to inhabit all different types of environment sampled in our study region indicates that they are less prone to deleterious effects of forest fragmentation and less threatened by extinction due to habitat loss and forest fragmentation.

Six species were considered edge-tolerant species being present in all forest-gradient transects but not observed in the pasture matrix: Copeoglossum nigropunctatum (Spix, 1825), Gonatodes hasemani (Griffin, 1917), G. humeralis, Iphisa elegans (Gray, 1851), N. fuscoauratus and Colobosaura modesta (Reinhardt and Luetken, 1862).

Considering forest specialists we found four species inhabiting only forest core at least $50 \mathrm{~m}$ from the edge: Hoplocercus spinosus (Fitzinger, 1843), B. dorbignyi, M. maximiliani and K. calcarta.

\section{Conclusion}

Most lizard species in this study avoided pasture (71\%), thus considered an ecological barrier for most of the species present in our study site at the southern Amazon. On the other hand, the majority of lizards ( 9 out of 15) were able to use edge and forest core as reported in previous studies in Cerrado (Colli, 2003) and Atlantic Forest (Silvano et al., 2003). Forest specialist lizards, occurring only $150 \mathrm{~m}$ from the edge towards forest core, are rare and their small populations are exclusively protected in the forest core. Lizard assemblages at the pasture matrix and forest edge are a nested subset of original assemblages present at the forestland. Furthermore, forest core of remaining fragments at the southern Amazon harbours all habitat-guilds of lizards, and they are therefore extremely important for preserving the entire array of the lizard assemblage.

\section{References}

AMARAL, DL. and FONZAR, BC., 1982. As regiões fitoecológicas, sua natureza e seus recursos econômicos. In Brasil. Ministério das Minas e Energia. Secretaria Geral. Projeto RADAMBRASIL. Folha SD. 21 Cuiabá: geologia, geomorfologia, pedologia, vegetação, uso potencial da terra. Rio de Janeiro. (vol. 26: Levantamento de Recursos Naturais).

ATMAR, W. and PATTERSON, BD., 1993. The measure of order and disorder in the distribution of species in fragmented habitats. Oecologia, vol. 96, no. 3, p. 373-382. http://dx.doi.org/10.1007/ BF00317508.

BARBOSA, O. and MARQUET, PA., 2002. Effects of forest fragmentation on the beetle assemblage at the relict forest of Fray Jorge, Chile. Oecologia, vol. 132, no. 2, p. 296-306. http:// dx.doi.org/10.1007/s00442-002-0951-3.

BIERREGAARD JUNIOR, RO. and LOVEJOY, TE., 1989. Effects of forest fragmentation on Amazonian understory bird communities. Acta Amazonica, vol. 19, p. 215-241.

BIERREGAARD JUNIOR, RO., LOVEJOY, TE., KAPOS, V., SANTOS, AA. and HUTCHINGS, RW., 1992. The biological dynamics of tropical rainforest fragments. BioSciences, vol. 42, no. 11, p. 859-866. http://dx.doi.org/10.2307/1312085.
BIERREGAARD JUNIOR, RO. and STOUFFER, P., 1997. Understory birds and dynamic habitat mosaics in Amazonian rainforests. In LAURANCE, WF. and BIERREGAARD JUNIOR, RO. (Eds.). Tropical Forest Remnants: Ecology, Management, and Conservation of Fragmented Communities. Chicago: University of Chicago Press. p. 138-155.

Brasil. Ministério da Ciência, Tecnologia e Inovação. Conselho Nacional de Desenvolvimento Científico e Tecnológico - CNPq, 1985. Pesquisa Ecológica na Região do Polonoroeste. Brasília. $130 \mathrm{p}$.

BROWN JUNIOR, KS. and HUTCHINGS, RW., 1997. Distrubance, fragmentation, and the dynamics of diversity in Amazoninan forest butterfiles. In LAURANCE, WF. and BIERREGAARD JUNIOR, RO. (Eds.). Tropical Forest Remnants: Ecology, Management, and Conservation of Fragmented Communities. Chicago: University of Chicago Press. p. 91-110.

CAMPBELL, HW. and CHRISTMAN, SP., 1982. Field techniques for herpetofaunal community analysis. In SCOTT JUNIOR, NJ. (Ed.). Herpetological Communities. Washington: Wildlife Research Report 13, Fish and Wildlife Service. p. 193-200.

CARDILLE, JA. and FOLEY, JA., 2003. Agricultural land use change in Brazilian Amazonia between 1980 and 1995: Evidence from integrated satellite and census data. Remote Sensing of Environment, vol. 87, no. 4, p. 551-562. http://dx.doi.org/10.1016/j. rse.2002.09.001.

CARVALHO, KS. and VASCONCELOS, HL., 1999. Forest fragmentation in central Amazônia and its effects on litter-dwelling ants. Biological Conservation, vol. 91, no. 2-3, p. 151-157. http:// dx.doi.org/10.1016/S0006-3207(99)00079-8.

CECHIN, SZ. and MARTINS, M., 2000. Eficiência de armadilhas de queda (pitfall traps) em amostragens de anfíbios e répteis no Brasil. Revista Brasileira de Zoologia, vol. 17, no. 3, p. 729-740. http://dx.doi.org/10.1590/S0101-81752000000300017.

COLLI, GR., 1991. Reproductive ecology of Ameiva ameiva (Sauria, Teiidae) in the Cerrado of Central Brazil. Copeia, vol. 1991, no. 4, p. 1002-1012. http://dx.doi.org/10.2307/1446095.

COLLI, GR., 2003. Estrutura de taxocenoses de lagartos em fragmentos naturais e antrópicos de Cerrado. In Claudino-Sales, V. (Ed). Ecossistemas Brasileiros: Manejo e Conservação. Fortaleza: Expressão Gráfica e Editora. p. 171-178.

COLLI, GR., ACCACIO, GM., ANTONINI, Y., CONSTANTINO, R., FRANCESCHINELLI, EV., LAPS, RR., SCARIOT, A., VIEIRA, MV. and WIEDERHECKER, HC., 2003. A Fragmentação dos Ecossistemas e a Biodiversidade Brasileira: uma Síntese. In RAMBALDI, DM. and OLIVEIRA, DAS. (Eds.). Fragmentação de Ecossistemas: Causas, efeitos sobre a biodiversidade e recomendações de políticas públicas. Brasília: Ministério do Meio Ambiente/ Secretaria de Biodiversidade e Florestas. p. 317-324.

COLWELL, RK., 2005. Program EstimateS 7: user's guide. Storrs: University of Connecticut. Available from: $<$ http:/viceroy. eeb.uconn.edu/estimates>.

DIDHAM, RK., 1997. An overview of invertebrate responses to forest fragmentation. In WATT, AD., STORK, NE. and HUNTER, MD. Forest and Insects. London: Chapman/Hall. p. 303-320.

FAGAN, WF., CANTRELL, RS. and COSNER, C., 1999. How Habitat Edges Change Species Interactions. American Naturalist, vol. 153, no. 2, p. 165-182. http://dx.doi.org/10.1086/303162.

FAHRIG, L. and MERRIAM, G., 1994. Conservation of fragmented populations. Conservation Biology, vol. 8, no. 1, p. 50-59. http:// dx.doi.org/10.1046/j.1523-1739.1994.08010050.x. 
FEARNSIDE, PM., 1999. Biodiversity as an environmental service in Brazil's Amazonian forests: risks, value and conservation. Environmental Conservation, vol. 26, no. 4, p. 305-321. http:// dx.doi.org/10.1017/S0376892999000429.

FISCHER, J., LINDENMAYER, DB., BARRY, S. and FLOWERS, E., 2005. Lizard distribution patterns in the Tumut fragmentation "Natural Experiment" in south-eastern Australia. Biological Conservation, vol. 123, no. 3, p. 301-315. http://dx.doi.org/10.1016/j. biocon.2004.11.018.

FOWLER, G., SILVA, CA. and VENTICINQUE, E., 1993. Size, taxonomic and biomass distributions of flying insects in Central Amazonia: Forest edge vs. understory. Revista de Biologia Tropical, vol. 3, p. 755-760.

GASCON, C., LOVEJOY, TE., BIERREGAARD JUNIOR, RO., MALCOLM, JR., STOUFFER, PC., VASCONCELOS, HL., LAURANCE, WF., ZIMMERMAN, B., TOCHER, M. and BORGES, S., 1999. Matrix habitat and species richness in tropical forest remnants. Biological Conservation, vol. 91, no. 2-3, p. 223-229. http://dx.doi.org/10.1016/S0006-3207(99)00080-4.

GREENBERG, CH., NEARY, DG. and HARRIS, LD., 1994. A comparison of herpetofaunal sampling efectiveness of pitfall, single-ended, and double-ended funnell traps used with drift fences. Journal of Herpetology, vol. 28, no. 3, p. 319-324. http:// dx.doi.org/10.2307/1564530.

GUIMARÃES JUNIOR, PR. and GUIMARÃES, P., 2006. Improving the analyses of nestedness for large sets of matrices. Environmental Modelling \& Software, vol. 21, no. 10, p. 15121513. http://dx.doi.org/10.1016/j.envsoft.2006.04.002.

HOKIT, DG., STITH, BM. and BRANCH, LC., 1999. Effects of landscape structure in Florida scrub: a opulation perspective. Ecological Applications, vol. 9, no. 1, p. 124-134. http://dx.doi. org/10.1890/1051-0761(1999)009[0124:EOLSIF]2.0.CO;2.

ISHINO, MN., DE SIBIO, PR. and ROSSI, MN., 2012. Edge effect and phenology in Erythroxylum tortuosum (Erythroxylaceae), a typical plant of the Brazilian Cerrado. Brazilian Journal of Biology, vol. 72, no. 3, p. 587-594. http://dx.doi.org/10.1590/ S1519-69842012000300023.

LAURANCE, WF., 1991. Edge effects in tropical forest: application of a model for the design of nature reserves. Biological Conservation, vol. 57, no. 2, p. 205-219. http://dx.doi.org/10.1016/00063207(91)90139-Z

LAURANCE, WF. and YENSEN, E., 1991. Predicting the impacts of edge effects in fragmented habitats. Biological Conservation, vol. 55, no. 1, p. 77-92. http://dx.doi.org/10.1016/0006-3207(91)90006-U.

LAURANCE, WF., 2000. Do edge effects occur over large spatial scales? Trends in Ecology \& Evolution, vol. 15, no. 4, p. 134-135. http://dx.doi.org/10.1016/S0169-5347(00)01838-3. PMid:10717681

LAURANCE, WF., LOVEJOY, TE., VASCONCELOS, HE., BRUNA, EM., DIDHAM, RK., STOUFFER, FC., GASCON, C., BIERREGAARD, RO., LAURANCE, SG. and SAMPAIO, E., 2002. Ecosystem decay of amazonian forest fragments: a 22-year investigation. Conservation Biology, vol. 16, no. 3, p. 605-618. http://dx.doi.org/10.1046/j.1523-1739.2002.01025.x.

LIMA, AP., SUÁREZ, FIO. and HIGUCHI, N., 2001. The effects of selective logging on the lizards Kentropyx calcarata, Ameiva ameiva, and Mabuya nigropunctata. Amphibia-Reptilia, vol. 22, no. 2, p. 209-216. http://dx.doi.org/10.1163/15685380152030436.

LOVEJOY, ET., BIERREGAARD JUNIOR, RO., RYLANDS, AB., MALCOLM, JR., QUINTELA, CE., HARPER, LH., BROWN JUNIOR, KS., POWELL, AH., POWELL, GVN.,
SCHUBART, HO. and HAYS, MB., 1986. Edge and other effects of isolation on amazon forest fragments. In SOULÉ, ME. (Ed.). Conservation Biology. The science of scarcity and diversity. Sunderland: Sinauer. p. 257-285.

MURCIA, C., 1995. Edge effects in fragmented forests: implications for conservation. Trends in Ecology \& Evolution, vol. 10, no. 2, p. 58-62. http://dx.doi.org/10.1016/S0169-5347(00)88977-6. PMid:21236953

OLIVEIRA, VA., AMARAL-FILHO, ZP. and VIEIRA, PC., 1982. Pedologia. In Brasil. Ministério das Minas e Energia. Secretaria Geral. Projeto RADAMBRASIL. Folha SD. 21 Cuiabá: geologia, geomorfologia, pedologia, vegetação, uso potencial da terra. Rio de Janeiro. (vol. 26: Levantamento de Recursos Naturais).

PRIMACK, RB. and RODRIGUES, E., 2001. In RODRIGUES, E. (Ed.). Biologia da conservação. 328 p.

RESENDE, MS., SANDANIELO, A. and COUTO, EG., 1994. Zoneamento agroecológico do Sudoeste do Estado de Mato Grosso. Cuiabá: EMPAER/EMBRAPA. Documentos 4.

RICKETTS, TH., 2001. The matrix matters: effective isolation in fragmented landscapes. American Naturalist, vol. 158, no. 1, p. 87-99. http://dx.doi.org/10.1086/320863. PMid:18707317

RODRIGUES, E., 1998. Edge effects on the regeneration of forest fragments in south Brazil. Cambridge: Harvard University. $192 \mathrm{p}$. $\mathrm{PhD}$ thesis at Department of Organismic and Evolutionary Biology.

SANTOS-FILHO, M., SILVA, DJ. and SANAIOTTI, TM., 2008. Edge effects and landscape matrix use by a small mammal community in fragments of semideciduous submontane forest in Mato Grosso, Brazil. Brazilian Journal of Biology $=$ Revista brasileira de biologia, vol. 68, no. 4, p. 703-710. http://dx.doi. org/10.1590/S1519-69842008000400004. PMid:19197487

SARTORIUS, SS., VITT, LJ. and COLLI, GR., 1999. Use Of naturally and anthropogenically disturbed habitats in Amazonian rainforest by the Teiid lizard Ameiva ameiva. Biological Conservation, vol. 90, no. 2, p. 91-101. http://dx.doi.org/10.1016/ S0006-3207(99)00019-1.

SCHLAEPFER, MA. and GAVIN, TA., 2001. Edge effects on lizards and frogs in tropical forest fragments. Conservation Biology, vol. 15 , no. 4, p. 1079-1090. http://dx.doi.org/10.1046/j.15231739.2001.0150041079.x.

SILVANO, DL., COLLI, GR., DIXO, MBO., PIMENTA, BVS. and WIEDERHECKER, HC., 2003. Anfíbios e Répteis. In RAMBALDI, DM. and OLIVEIRA, DAS. (Eds.). Fragmentação de Ecossistemas: Causas, efeitos sobre a biodiversidade e recomendações de políticas públicas. Brasília: Ministério do Meio Ambiente/Secretaria de Biodiversidade e Florestas. p.183-200.

STOUFFER, PC. and BIERREGAARD JUNIOR, RO., 1995. Effects of forest fragmentation on understory hummingbirds in Amazonian Brazil. Conservation Biology, vol. 9, no. 5, p. 10851094. http://dx.doi.org/10.1046/j.1523-1739.1995.9051072.x-i1 .

STRÜSSMANN, C., 2000. Herpetofauna. In ALHO, CJ. Fauna silvestre da região do rio Manso - MT. Brasília: IBAMA. p. 153-189.

VITT, LJ. and COLLI, GR., 1994. Geographical ecology of a neotropical lizard: Ameiva ameiva (Teiidae) in Brazil. Canadian Journal of Zoology, vol. 72, no. 11, p. 1986-2008. http://dx.doi. org/10.1139/z94-271.

WILKINSON, L., 1998. SYSTAT: the system for statistics. Evanston: Systat Inc. 